\title{
Flow of funds analysis: A combination of Roman law, accounting and economics
}

\author{
Kazusuke Tsujimura ${ }^{\mathrm{a}, \mathrm{b}}$ and Masako Tsujimura ${ }^{\mathrm{c}, \mathrm{d}, *}$ \\ ${ }^{a}$ Emeritus Professor, Keio University, Tokyo, Japan \\ ${ }^{\mathrm{b}}$ Professor of Economics, Meisei University, Tokyo, Japan \\ ${ }^{\mathrm{c}}$ Lecturer of Economics, Rissho University, Tokyo, Japan \\ ${ }^{\mathrm{d}}$ Research Economist, Keio Economic Observatory, Keio University, Tokyo, Japan
}

\begin{abstract}
The 1920s was a decade of great inventions and of substantial productivity growth; people found it difficult to understand why the Great Depression could follow a decade of unprecedented prosperity. Wesley Mitchell and Morris Copeland, who have initiated the flow of funds analysis, urged a better understanding of the circulation of funds between the financial and nonfinancial economy. Since funds, which is the sole currency in the pure credit economy we live today, exist only in the bank's balance sheets, accounting is a necessity for the virtual currency. Furthermore, the assets and liabilities in the bankers' accounts mean claims and obligations so that law is another prerequisite for the existence of funds. The present paper is an attempt to detail the historical background of the 'flow of funds' analysis tracing back to ancient Rome to clarify the interdependence between law, accounting and economics; and to revive the original idea of Mitchel and Copeland - to understand the interactions between the financial and nonfinancial economy.
\end{abstract}

Keywords: Pure credit economy, virtual currency, ancient Rome, argentarii, double entry system

\section{History of the Flow-of-Funds Accounts}

Flow of funds analysis began in the 1940s as a branch of national accounting, then known as social accounting, ${ }^{1}$ which referred to the preparation and interpretation of overall economic statistics in the form of financial statements - that is, in the form of balancing accounts for the economy as a whole that were analogous to the statements prepared for individual business. The flow of funds system is designed to bring the financial activities of an economy into explicit statistical relationship with one another and into direct relation to data on the nonfinancial activities that generate income and production. The purpose of the account is to provide, systematically, the aggregate measures of transactions needed to identify both influ-

\footnotetext{
*Corresponding author: Masako Tsujimura, Faculty of Economics, Rissho University, 4-2-16 Osaki, Shinagawa, Tokyo 1418602, Japan. Tel.: +81 35487 3356; E-mail: tsujimura@ ris.ac.jp.

${ }^{1}$ The terminology is attributable to Hicks [1].
}

ences of the nonfinancial economy on financial markets and reciprocal influences of financial market developments on demand for goods and services, sources of amounts of saving and investment, and the structure of income. Reference must be made to the influence of Van Cleeff [2] and Derksen [3], and so of Stone [4] and Aukrust [5]. Mitchell [6] and Copeland's [7-9] system of Moneyflows Accounts, widely known as Flow of Funds Accounts today, ${ }^{2}$ should be mentioned not only for specific ideas but also for their vigorous advocacy of an integrated structure. The system they have developed incorporates not only current productive activity and the distribution and transfer of income, but also those transactions which help finance income, transfer and production flows.

The Moneyflows Accounts conceive of the economy as composed of groups of units that are continuously

\footnotetext{
${ }^{2}$ The world finally departed from the gold standard system in 1971; the Moneyflows Accounts was so called because it was designed during the gold standard era.
} 


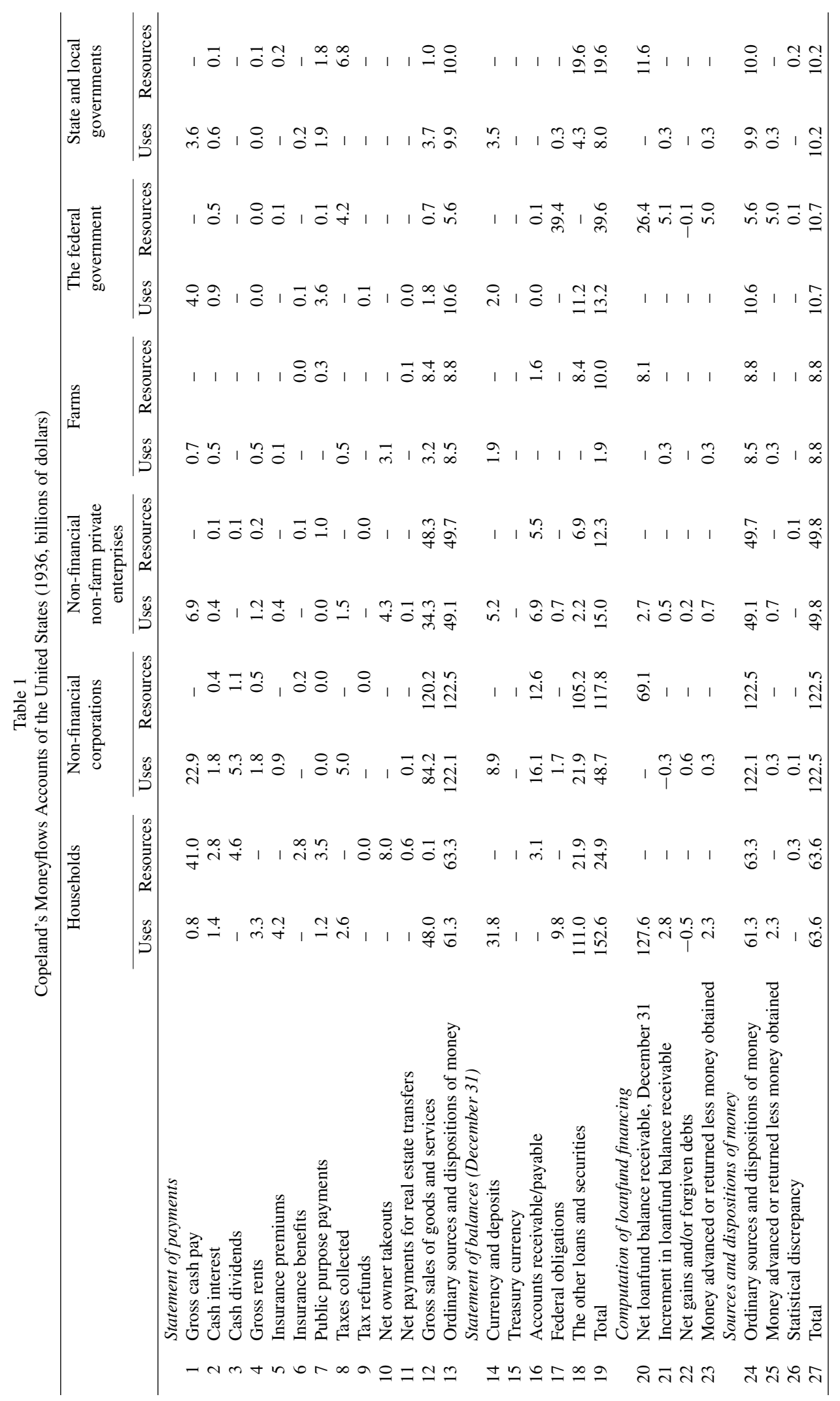




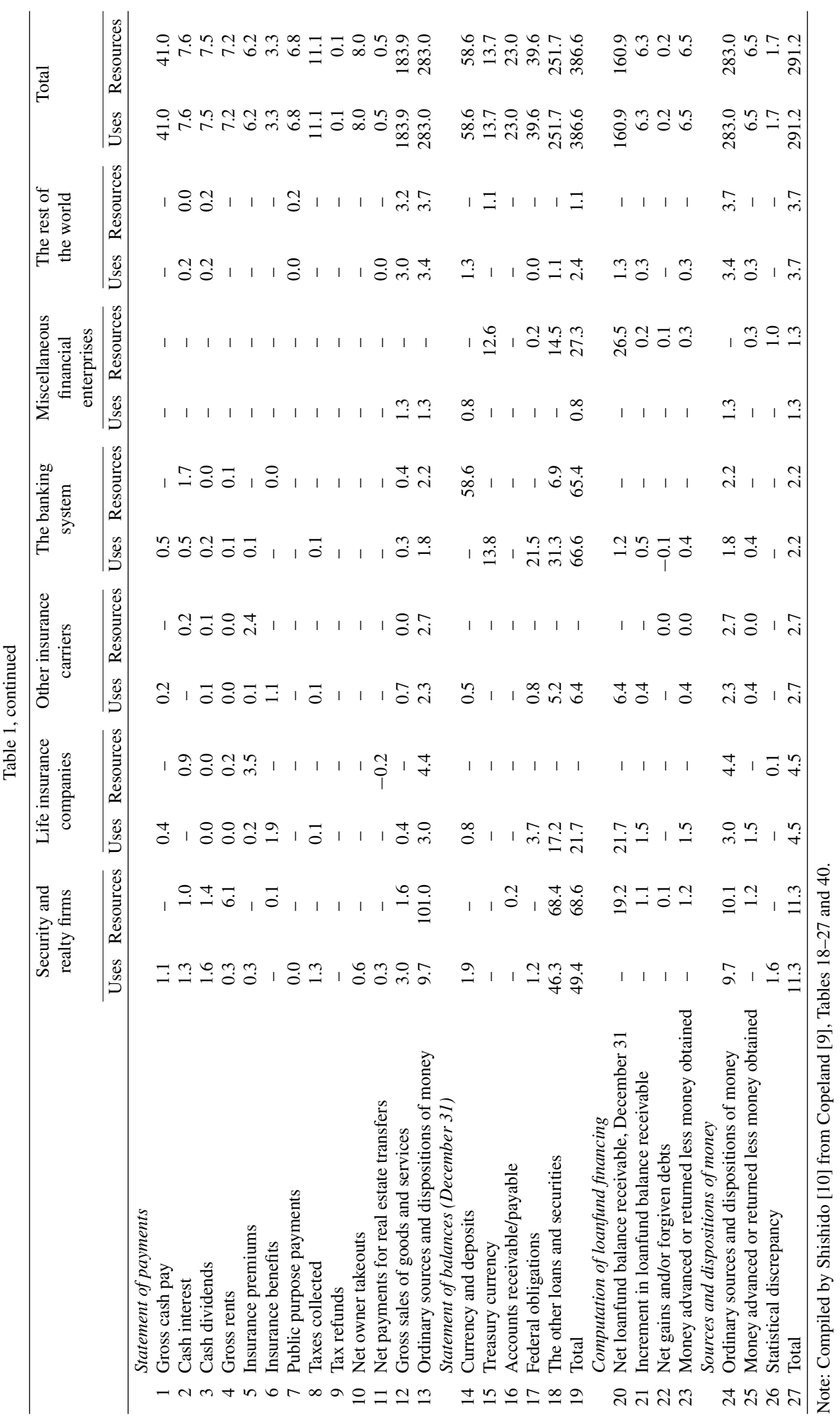


making and receiving payments. Mitchel summarizes the framework of the accounts in the following manner:

"For each group, we imagine that a double-entry account is kept. On one side, the account shows all payments received by units in the group. These payments are classified by (1) unit and group making the payment, (2) that for which the payment is received, and (3) form of currency in which the payment is received. On the other side, the account shows all payments made by units in the group, with expenditures classified in a corresponding fashion. When the accounts for the four groups are completed for a year, they are fitted together. Every payment is reported twice, once in the account of the payer and once in the account of the payee. The detailed classifications of receipts and expenditures should be sufficiently uniform in the several groups to let one add similar items in the group totals." (Mitchel [6] as reproduced in Copeland [9, p. 3].)

The statements of the sectors tell who has paid and who has received how much on account of various types of transactions or objects of payment; the part of the statements is referred to as 'statement of payments'. The statements also show the financial assets owned and liabilities incurred by each sector; the part of the statements is referred to as 'statement of balances'. Table 1 is the bird's eye view of the total system of the Moneyflows Accounts, which has been compiled by Shishido [10] from Tables 18-27 and 40 of Copeland [9]. It is remarkable to find that the presentday System of National Accounts (SNA), which is supposed to be based on the product-flow rather than on the funds-flow method after the 1968 revision that has been supervised by Richard Stone, has much resemblance to the Moneyflows Accounts, at least in appearance, than to the income-output-expenditure table ${ }^{3}$ presented in Meade and Stone [12]. The differences lie only in the accounting principles.

The name 'flow of funds' is attributable to Flow of Funds in the United States 1939-1953, which was the first official statistics based on the Mitchell and Copeland's idea, published by the Board of Governors of the Federal Reserve System (the Fed) in 1955 [13]. ${ }^{4}$

\footnotetext{
${ }^{3}$ The table is a depiction of the macroeconomic identity between production, distribution and consumption, which is originally suggested by Kuznets [11].

${ }^{4}$ The early history of the flow of funds accounts is detailed in De Bonis and Gigliobianco [14].
}

The Bank of England (BOE) was regularly publishing statements named Daily Flow of Funds from the beginning of eighteenth century ${ }^{5}$ until the 1970 s, ${ }^{6}$ which recorded the 'flow of funds' between the BOE and the private sector due to the changes in the outstanding banknotes and deposits, and in the corresponding assets $;^{7}$ it is said to be the origin of the word. ${ }^{8}$ The Fed is still publishing the Flow of Funds Accounts today under the name of Financial Accounts even though the scope of the statistics has been narrowed in 1959 so that the present-day statistics no longer include the nonfinancial transactions. ${ }^{9}$

Developing quarterly Flow of Funds Accounts was the principal activity at the Fed between 1955 and 1959.

"After the 1955 Flow of Funds publication there was growing demand on the flow-of-funds group for a quarterly form of the accounts. Management wanted something that could be much more timely and current for Board purposes than a set of annual accounts that required most of a year to put together. ... The quarterlies included major and irreversible changes in the macroanalysis and social accounting, and one could begin to see the relation here to Richard Stone's capital and reserve accounts that were in his landmark memo of $1947 .^{10}$ ... This had a major effect on the form of nonfinancial transactions in the system. ... This led directly to a form of matrix and of sector analysis in which the totals of saving and investment are

\footnotetext{
${ }^{5}$ Although he mainly used the BOE balance sheet as his data source, Ricardo [15], the first academic author who systematically analyzed the 'flow of funds' between a central bank and the public, was aware of the statistics.

${ }^{6}$ The statements are simply known as Daily Flows in more recent years. In 2015, the U.K. Office for National Statistics and the BOE started to publish so-called Flow of Funds Experimental Statistics (Enhanced Financial Accounts) that explores the sectoral interconnectedness within the economy and analyses the lender-borrower relationships in the context of risk exposures. For more details, see Banks [16].

${ }^{7}$ An equivalent of 'Factors Affecting Reserve Balances' in the Fed's terminology.

${ }^{8}$ Another possibility is that the Fed just borrowed the name from business accounting. Until 1980s, when business accountants began to switch from cash basis to accrual basis, profit and loss statements were often referred to as funds-flow statements. See Footnote 37 of Tsujimura and Tsujimura [17].

${ }^{9} 1959$ revised U.S. Flow of Funds Accounts had much similarity to Kredittmarkedstatistikke, which had been published by the Norges Bank, the central bank of Norway, since 1952. The Bank of Japan also started to publish similar statistics called Shikin Junkan Kanjo in 1958 .

${ }^{10}$ Listed as Stone [4] at the end of the paper.
} 
pivotal, where, that is, for each sector the total of net current receipts equals, in a statistically perfect world, the total of capital formation and net financial investment. The identity here can be stated in several ways, just as the equation of exchange can, but the form that appeared in 1959 with the quarterly accounts - saving equals investment - is the one that brings flow-of-funds statistics directly into the social account structure that Stone described in 1947." (Taylor [18, pp. 104-105].) $)^{11}$

As Keynes [19, p. 175] contended, the classical theory of loanable funds regarded "the rate of interest as the factor which brings the demand for investment and the willingness to save into equilibrium with one another". In the diagram, which Keynes reproduced from the best-selling textbook of neoclassical economics by Carver [20, p. 243], the saving curve is illustrated as upward sloping, and the investment curve is depicted as downward sloping so that the two curves have an intersection $^{12}$ (see Fig. 1). Carver [20, p. 246] also mentioned the possibility that the saving curve had a downward rather than upward slope. The idea was first conceived by Cassel [21, p. 144]: "persons desiring to procure for themselves a certain annual income are compelled to accumulate a much larger capital if the rate of interest is low". In other words, a person who wants to keep his/her consumption level unaltered before and after retirement will increase saving if the interest rate is lowered, so that a downward saving curve might not be unusual. It is a problematic situation because the market alone cannot determine the interest rate especially if the two curves have no intersection as depicted in Fig. 2. In either case, since it was (and still is) practically difficult to empirically depict the saving and investment curves, the Fed was obliged to constantly observe the saving-investment gap and set the Federal Funds Rate so to minimize the gap. The changes of the Flow of Funds Accounts were necessary for the Fed to promptly publish the data of 'net financial surplus', which is easily obtainable from balance sheets

\footnotetext{
${ }^{11}$ Stephen P. Taylor was a longtime Chief of Flow of Funds Section at the Fed.

${ }^{12}$ Until 2009, when Sweden's Riksbank started to utilize negative interest rates as a policy tool, there was a limit, what economists called the 'zero lower bound'; it was long believed that when it comes to interest rates, zero is as low as you can go. If it is the case, there remains a saving-investment gap when the equilibrium interest rate is negative even if the saving curve is upward sloping and the investment curve is downward sloping; Carver [20, p. 235] was well aware of this possibility from the experience of the Panic of the 1890s.
}

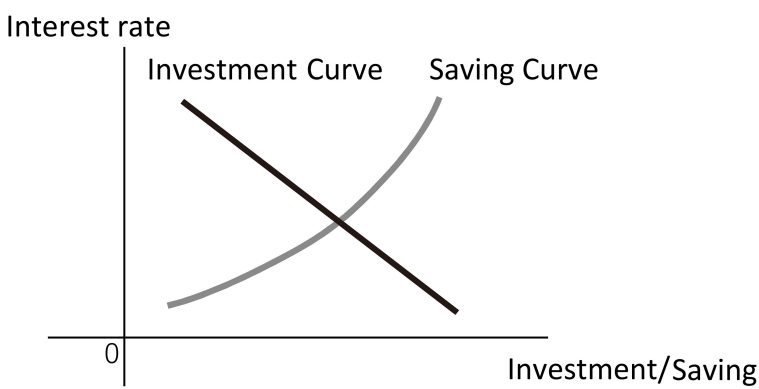

Fig. 1. Upward-sloping saving and downward-sloping investment curves.

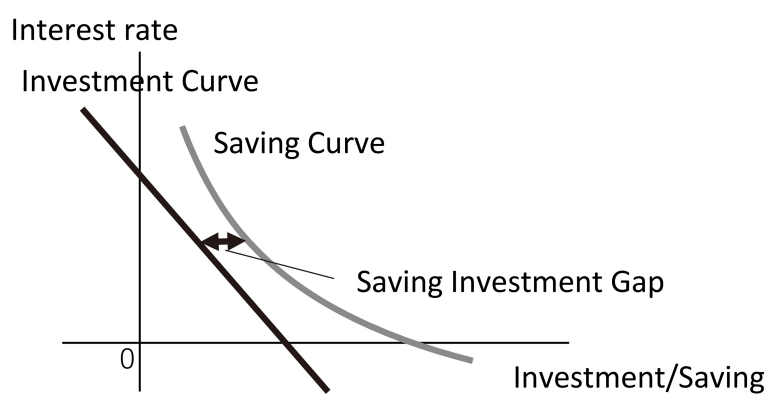

Fig. 2. Downward-sloping saving and investment curves.

as the changes in net worth, as a proxy to the savinginvestment gap.

"The changes [of the Flow-of-Funds statistics] were forced partly by practical considerations, because a great deal of the nonfinancial detail on imputations and forms of spending and receipts existed only on an annual basis. In those precomputer days the conversion of annual imputations into quarterly series was far too time-consuming to be a realistic possibility. This had a major effect on the form of nonfinancial transactions in the system. Gone were accounts for wages paid and received by sector, for interest paid and received by sector, and so forth. Instead there were statements of consumer income and consumption, business profits and investment, and the like that were based directly on NIPA aggregates in published quarterly form and that differed in structure from sector to sector. This meant no homogeneity across sectors in nonfinancial activity above the level of saving and capital formation, and as a result it meant that the flow-of-funds matrix - the defining form of flow-of-funds analysis - became very much truncated in its nonfinancial sectors." (Taylor [18, p. 104].) 


\section{Roaring Twenties and the Great Depression}

After the drastic changes in the statistics, the present-day Flow-of-Funds Accounts or Financial Accounts as it is known today covers only the lenderborrower relationship that corresponds to financial transactions rather than the more general payer-payee relationship that includes both real and financial transactions. As Taylor [18, p. 104] remarks, "it is these changes, more than that followed, that may have let Copeland feel that moneyflows analysis had been lost somewhere along the way". To ensure a nonrecurrence of the bitter experience of the Great Depression, Mitchell and Copeland urged a better understanding of the circulation of funds, the means of payment, in the macro-economy.

"We do know, however, that the flow of payments does not adjust itself automatically to the flow of goods men are able to produce and need to consumer. Indeed, several theorists have argued that cyclical fluctuations in business activity are due primarily to recurring changes in the relative size of these two flows. The findings this investigation promise should put us in a far better position to diagnose our recurrent chills and fevers, and to seek remedies." (Mitchell [22, pp. 61-62].)

"Our economy has suffered in the past from business depressions and unemployment, and in spite of the present high level of business activity there is no reason to think depressions have been eliminated. If we look beyond the immediate situation, unemployment is still our most important economic problem. Because we live in a money economy where moneyflows play an important role in organizing economic activity, a better understanding of moneyflows should help us toward a better understanding of the problem of maintaining reasonably full employment." (Copeland [8, p. 254].)

It is well known that the Great Depression was triggered by a stock market crash of 1929 , however, what caught their attention was the dramatic contrast between the 1920s and 1930s. ${ }^{13}$ Before ending production in 1927, the Ford Motor Company produced more than 15 million automobile christened Ford Model T at low cost by adopting the assembly-line production method making it possible for the common middle-

\footnotetext{
${ }^{13}$ The following narratives are brief summaries of Allen [23,24].
}

class American family to own a car. ${ }^{14}$ Henry Ford also introduced the Fordson Model F, a wildly popular mass-produced tractor, spreading the productivity revolution in manufacturing into agriculture. The electrically recorded audio disks appeared for the first time in 1925; Western Electric integrated electrical microphones, electronic signal amplifiers and electromechanical recorders into one complete system, which was adopted by major U.S. record labels. Two years later, in 1927, the first commercial talking (and singing) picture Jazz Singer was produced by Warner Brothers ${ }^{15}$ synchronizing the sound with film. ${ }^{16}$ The Americans who finally found leisure time thanks to the high productivity crowded the movie theaters. The National Broadcasting Company began regular broadcasting with telephone links between New York and other Eastern cities; the Red Network offered commercially sponsored entertainment and music programming; the Blue Network broadcast news and cultural programs with no sponsors. ${ }^{17}$

The great inventions and the substantial productivity growth of the Roaring Twenties surely brought a consumption and investment explosion; the corporate profits surged so did the stock and land prices. However, after the Black Tuesday in the fall of 1929, the U.S. economic landscape changed dramatically. ${ }^{18}$ The plunge in stock and real estate market rapidly cooled the consumption fever. The manufacturing plants went idle so did the workers. Many families did not have money to buy things, and as a consequence, consumer demand for manufactured goods fell off even further. In the early 1930s, crop prices also dropped so low that many farmers who were in debt as a result of their heavy investment in new machinery went bankrupt and lost their farms as depicted in John Steinbeck's novels. People found it difficult to understand how such a severe depression could follow a decade of the unprecedented prosperity. Mitchell and Copeland sought the answer in the payer-payee relationship between the institutional sectors; they surmised that funds, the means of payment, are the lifeblood that circulates around the economy.

\footnotetext{
${ }^{14}$ See Banham [25] for the technological development at the Ford Motor Company.

${ }^{15}$ See Sennett [26, pp. 31-33], for details.

${ }^{16}$ Large soundtrack records were played on a turntable mechanically interlocked with the projector.

${ }^{17}$ See Leblebici et al. [27] for details.

${ }^{18}$ Galbraith [28] details the entire history of the Crash.
} 
Since funds, which is the sole currency in the pure credit economy ${ }^{19}$ we live today, exist only in the bank's balance sheets, accounting is a necessity for the virtual currency. Furthermore, the assets and liabilities in the bankers' accounts mean claims and obligations so that law is another prerequisite for the existence of funds. The present paper is an attempt to detail the historical background of the 'flow of funds' analysis, and to clarify the relationship, or rather interdependence, between law, accounting and economics.

Both philosophy and science rely on evidences as well as on logics. The difference between the two is the balance; if you put more emphasis on evidences than on logics, it is called science; if you rely more on logics than on evidences, it is referred to as philosophy. We should remember that the evidences and the logics are interdependent rather than independent. Since evidences are often given in numbers, such as GDP and net worth, insight into the functioning of an economy can be greatly enhanced by casting available information into a systematic and comprehensive structure of economic accounts. Application of accounting discipline to the organization of economic data aids in both collection and interpretation of economic and jurisprudential knowledge, for it highlights gaps in the basic statistics and clarifies interrelations among the parts of the structure. In the next section, we will discuss the origin of the concept of funds in relation to the banker's accounts of the ancient Rome, from which the quadruple entry bookkeeping, the backbone of the today's national accounting, stems.

\section{Roman law and the ancient bankers ${ }^{20}$}

The Duodecim Tabulae (Twelve Tables) was a set of laws inscribed on 12 bronze tablets ${ }^{21}$ created in the

\footnotetext{
${ }^{19}$ Wicksell [29] referred to it as 'pure system of credit'. After the U.S. have suspended dollar's convertibility to gold in 1971, the currencies of the world are no longer pegged to gold.

${ }^{20}$ This section is summarized mainly from Mommsen [30], Austin [31], Smith (ed.) [32] and Berger [33]. Argentarii's activities are detailed in Cicero's Epistulae ad Atticum (Letters to Atticus; 68-44 BCE) as well as in his speeches, such as Pro Fonteio (On behalf of Marcus Fonteius; 69 BCE) and Pro Caecina (On behalf of Caecina; $69 \mathrm{BCE})$; and the archeological evidences excavated from Pompeii are minutely recorded in De Petra [34].

${ }^{21}$ The original bronze tablets of the Duodecim Tabulae are said to have been destroyed when the Gauls sacked and burned Rome in the invasion of $387 \mathrm{BCE}$ so that we do not know how much of the text is missing and in what order the clauses were originally arranged However, the nineteenth and twentieth century attempts to reconstruct the Tabulae from the ancient literatures have handed us down at least some fragments. See Steinberg [35] for more information.
}

Roman Republic around 450 BCE. The laws relating to economic activities consist of two parts: jus in rem and jus in personam. Jus in rem is the exclusive dominion of a person over res; while res corporales are physical and tangible objects such as furniture, building, and land, res incorporales are intangible abstract things such as writing, music, and method of manufacture. Jus in personam or obligatio to be precise is an explicit agreement between specific parties, in which one party is obliged to do or to perform some specific duties on behalf of the other. For example, the Duodecim Tabulae stipulates that a purchaser of res does not get dominium until full payment is made. The purchaser of res gets possessio at the time of delivery and may be asserted against a third party, but may not be asserted against the vender until the payment is fulfilled. Dominium is the exclusive right to use (usus), to profit from (fructus), and to dispose of (abusus) a particular res. ${ }^{22}$ Possessio is the right to possession or occupancy; possessio allows the possessor to exclusively use, and to profit from the particular res without impairing the substance of the res, ${ }^{23}$ but does not allow disposing of it. ${ }^{24}$ The ideas are highly sophisticated; but the trouble was that Rome at that time had no minted coins to make payments. Romans started to produce coins only after 268 BCE. According to Naturalis Historia (Natural History; XXXIV), an early encyclopedia compiled in the first century CE, the Romans probably established an official currency unit, the as or a pound of bronze, at the beginning of the Republic era around $500 \mathrm{BCE}$. And yet the Lex Papiria Iulia, which is a Roman law of $430 \mathrm{BCE}$, provides that a fine as a penalty must be paid in aes rude (unworked lumps of bronze) and not in cattle, as hitherto was in use, with the equivalent of a sheep for ten asses and an ox for one hundred asses. $^{25}$

As for jus in personam, the Duodecim Tabulae did not solve but rather created problems because the law

\footnotetext{
${ }^{22}$ The following narratives are mainly based on the Book I of Hunter [36]

${ }^{23}$ Possessio in this context is referred to as usufructu in the Institutiones (the Institutes), one of the three books that comprise the Corpus Juris Civilis (the Code of Justinian), which was edited around $530 \mathrm{CE}$ in the Byzantine Empire.

${ }^{24}$ The distinction between dominium and possessio is an indispensable feature of Roman law. For example, locatio conductio rei (lease agreement), an jus in personam, can be defined as an agreement in which the dominus (owner) of a res agrees to transfer the possessio of the res to another party, for a duration of time, for an agreed purpose; and the counterparty promises to make pensio (payment) for it.

${ }^{25}$ See Cicero's De Re Publica (On the Republic; 51 BCE), II. 60; Belloni [37] details the episode.
} 
legalized the old Roman custom of nexum. Nexum was an ancient form of debt bondage contract in which the debtor pledged his/her person as collateral should he/she default on his/her loan or fail to fulfill any obligations. ${ }^{26}$ As the name Res Publica (Roman Republic) indicates, anything other than res propria, the res subject to private ownership, were res publicae so that they were subject to communio of the populus Romanus (Roman citizens). Communio is the right, which is shared by two or more people, to use, to profit from, and to dispose of a particular res; each co-owner may use and profit from the entire property in proportion to its share, however, no co-owner may dispose of or make any alteration to the res without the consent of the other co-owners. The idea of communio also applied to land so that, in the early republic era, people could freely graze their livestock in the abundant communa pasture (common pastures). We do not know exactly why but a great majority of the communa pasture was lost within the first two centuries of the establishment of the republic, though, one apparent reason for the loss was to make room for the construction of the Forum Romanum (Roman Forum). Afterall, the Latins were sheep farmers, and semi-nomadic shepherds in their origin; thousands of people lost their livelihood and went into heavy debt. Under the nexum contract, a debtor became a nexus/nexa (bond slave) if he/she failed to pay the debt on or before the promised date; he/she was not freed until the debt is paid off. ${ }^{27}$

Lex Poetelia Papiria that was enforced in $326 \mathrm{BCE}$ nullified nexum and introduced a new form of contract known as mutuum; the law forbade holding debtors in bondage for their debt and required instead that the debtor's property be used as collateral. ${ }^{28}$ All people confined under the nexum contract were released, and nexum as a form of legal contract was forbidden there-

\footnotetext{
${ }^{26}$ See De Zulueta [38] for details.

${ }^{27}$ The institution of patria potestas, which was also stipulated in the Duodecim Tabulae, allowed a pater (head of family) to offer any familiaris of his household as nexus as a substitute for himself; it meant that the patres could sell any members of their families, kinfolks and servi (live-in workers) alike, under the guise of personal collateral. This caused massive moral hazard among patres and led to the promulgation of Lex Poetelia Papiria, which abolished the institution of nexum. After the introduction of the lex, the institution of patria potestas and the system of familiares extendi (extended familes) quickly disappeared, at least in the urban middle class, because family members were no longer assets that could be sold but were mouths to be fed - costly burdens for the patres. See De $\mathrm{Zu}$ lueta [38] and Smith (ed.) [32, pp. 795-798].

${ }^{28}$ See Livy's Ab Urbe Condita Libri, VIII. 28; also see Schiller [39, pp. 209-211].
}

after. Mutuum as stipulated in the lex consisted of two pairs of jus in personam: the obligatio and the obligare. ${ }^{29}$ The obligatio is a contract in which the first party loans some res to the second party who is allowed to use or to profit from it, and also to consume it or to sell it to another, but is bound to return an equivalent of the original res. The obligare is a contract in which the second party put up another res of equal value as a collateral; if the second party fails to fulfil its obligatio, the first party can seize the collateral or sell it to another to have its own claims paid, but cannot seek out the second party for any further compensation, even if the collateral does not cover the full value of the defaulted amount. ${ }^{30}$ Although the debtors generally welcomed the new law, Lex Poetelia Papiria alone did not solve the economic problems because many of the peasants, then known as plebes, had so little to offer as collateral. As a result, the Republic was obliged to absorb the unemployed people, many of them were $l i b$ erti (freedmen), by promoting new industries, namely trade and commerce. Two brand new systems to create jobs for the people who had no capital endorsement were established: the argentarii (notary bankers) and the auctiones (public auctions).

In its origin, the argentarii, later known as the commercial bankers of Rome, were notaries who were authorized by the Republic to document business transactions. ${ }^{31}$ Livy mentions in his well-known history book Ab Urbe Condita Libri (The History of Rome; IX. 40) that the silver shields, which decorated the argentarii's office, ${ }^{32}$ were a part of the distribution of war-booty from the Samnite Wars so that the existence of argentarii at Rome can be proved as early as 311 BCE. One remarkable feature in Rome was that the banking system emerged before the city minted its own coins. It was around $211 \mathrm{BCE}$ when the Romans created a coinage system, usually referred to as the Denarius System; ${ }^{33}$ however, a significant amount of coins started to circulate only after the coinage reform of

\footnotetext{
${ }^{29}$ The following narratives are mainly based on the Book II of Hunter [36]

${ }^{30}$ The practice was referred to as non recursus pecuniae creditae; it is the origin of the non-recourse loan.

${ }^{31}$ As a distinct class, the argentarii were more formally known as negotiatores stipes argentariae; the name implies that they were state approved professionals acting as business intermediaries or guarantors. See Smith (ed.) [32, pp. 130-132].

${ }^{32}$ All the argentarii of Rome were members of the collegium argentariorum, an equivalent of today's bankers association, and were carrying on business under one roof; Hunter [36, p. 455].

${ }^{33}$ See Harl [40, pp. 33-37].
} 
Augustus that took place in $23 \mathrm{BCE}^{34}$ Gaius' Institutiones (Institutes of Roman Law; IV. 126), written around $161 \mathrm{CE}$, confirms that the argentarii regularly took part in auctiones, a symbol of the Roman market economy. ${ }^{35}$ An auctio was a sort of public auction, either permanent or temporary market, which functioned much more as a present-day wholesale market. It was a praeco (auctioneer) who presided over an auctio and awarded the objects to the highest bidders while it was an argentarius who kept the register of the sales. ${ }^{36}$

The nineteenth-century discovery in Pompeii of the tabulae ceratae (wax-covered tablets) of Lucius Caecilius Iucundus, a first-century CE argentarius, represent the most illustrative preserved testimony on the daily operations of the argentarii. ${ }^{37}$ According to the archaeological evidences, the argentarii recorded the names of the vendor and the purchaser in addition to the details and the total value of the sold items into the official register known as auctionalis, on which seven witnesses inscribed their names and impressed seals. ${ }^{38}$ The argentarii put the auctionales into solid wooden boxes and stored them in a safe place; some of them were stored there for several decades. This practice suggests that the auctionales have doubled as certificates of pledge. The records of sale were also written into the argentarii rationes (banker's books), namely adversaria and rationes mensae. While an adversaria was a book that recorded all the banking transactions in the order of occurrence, a ratio mensa was a book that recorded each customer's transactions successively. ${ }^{39}$ The argentarius credit the seller's ratio mensa and debit the adversaria - the bank ledger; the argentarii referred to the book entries as credito. At the same time, the argentarius debit the buyer's ratio mensa and credit the adversaria; the argentarii referred to it as debito. ${ }^{40}$ This practice known as bilan-

\footnotetext{
${ }^{34}$ Augustus brought considerable amount of precious metal back from Alexandria to Rome in $30 \mathrm{BCE}$ by defeating Antony and Cleopatra; see Dundas [41]

${ }^{35}$ See Morcillo [42] for details.

${ }^{36}$ See Cicero's Pro Aulo Caecina (On behalf of Caecina; 69 BCE), VI. 16

${ }^{37}$ See De Petra [34]. Bove [43] documents more recent excavations in the area.

${ }^{38}$ See Mau [44], Chapter LVIII, for illustrations.

${ }^{39}$ See the first chapter of Petrucci [45] for more details.

${ }^{40}$ Thus, credito means "we (the argentarii) have credited the customer's account"; and debito means "we (the argentarii) have debited the customer's account". This is why the right-hand side of a ledger is customarily referred to as credit and the left-hand side as debit, not vice versa. The well-known accounting terminologies, debit and credit, are English translations for debito and credito, banking terminologies of the ancient Rome.
}

$\mathrm{cia}^{41}$ is considered to be the origin of double entry bookkeeping. Actually, there are four simultaneous entries of the amount of the proceeds; twice in the adversaria and once each in the vender's and purchaser's $r a$ tiones mensae. In the today's national accounting terminology, the former is known as vertical double entry, and the latter is called horizontal double entry; the combination of the two is referred to as quadruple entry. ${ }^{42}$

The credit from auction sales, which was known as uacua pecunia (virtual currency) ${ }^{43}$ or more simply as nomina, was transferred between the clients of argentarii as a means of payments; the practice was then called solutio imaginaria (virtual payment). The payment in uacua pecunia was widely accepted as a method of payment during the Republic era. ${ }^{44}$ Uacua pecunia is considered to be the origin of 'funds' as we refer to it today; funds are casually defined as the value deposited at a bank. ${ }^{45}$ Argentarii also often credited uacua pecunia to their customers' accounts on the condition that the customers would pay it back on or before an agreed date; this kind of operation was known as creditum. The lenders other than argentarii lend

\footnotetext{
${ }^{41}$ Bilancia literally means 'weigh (the object of sale) twice' with both the vender's and the purchaser's scale.

${ }^{42}$ The terminology first appeared in Copeland [8, p. 256]; Ruggles [46, pp. 23-27], also elaborated the idea as 'the four aspects of a transaction'. The copy of the book we own, which Ruggles has personally presented to Stone, carries a signature: "To Richard Stone who was responsible for more of this book than I was, Richard Ruggles".

${ }^{43}$ Pecunia, or currency in English, is a tool that is universally accepted as a medium of exchange in a particular area; the currency also serves as a uniform unit of account in the area. Meanwhile moneta, or money in English, means minted coins because, in Rome, the coins were produced at the mint in the Templum Iunonis Monetae (temple of Juno Moneta) on the Capitoline Hill not far from the Forum. Iunonis Monetae was an epithet of the Roman goddess Iuno; etymologically speaking, the word monetae came from mater (mother).

${ }^{44}$ Aforementioned Cicero's Epistulae ad Atticum, I. 9, says that delegatio (bank transfer), which was casually known as per mensam or de mensa (through the bank; literally means 'over the counter'), was the most widely used payment method even after the introduction of coinage; and direct payment in monetae (minted coins) between native Romans was an exceptional case so that it was called ex area or de domo meaning 'out of place'.

${ }^{45}$ In most of the countries, the depository institutions, casually known as commercial banks, are licensed by the government and are governed by the law; thus, the funds, the deposited value, is indirectly authorized by the state. In contrast to this, cryptocurrency, such as Bitcoin, is a type of currency that exists only on the computer network with no particular administrator; new units of currency are generated by the computational solution of certain mathematical problems, and the transactions are secured by encrypted blockchain that contains the entire history of the transactions.
} 
Table 2

Frisch's flow of funds table

\begin{tabular}{|c|c|c|c|c|c|c|}
\hline & \multicolumn{2}{|c|}{ Central bank } & \multicolumn{2}{|c|}{ Commercial banks } & \multicolumn{2}{|c|}{ Nonbank sector } \\
\hline & Payment & Receipt & Payment & Receipt & Payment & Receipt \\
\hline Banknotes in circulation & & $\times$ & $\times$ & & $\times$ & \\
\hline Reserve deposit & & $x$ & $\times$ & & & \\
\hline Bank deposits & & & & $\times$ & $\times$ & \\
\hline Bank lendings & & & $\times$ & & & $\times$ \\
\hline Open market operations & $\times$ & & & $x$ & & $x$ \\
\hline Net payment & & $\times$ & & $\times$ & & $\times$ \\
\hline
\end{tabular}

Note: Compiled by the authors from Frisch [50], Table 1, p. 57.

funds in their possession; this practice was referred to as mutuum if collateralized and known casually as pecuniam credere otherwise. ${ }^{46}$

\section{Concluding remarks}

Funds was one of the popular academic topics, both in law and economics, at the turn of the nineteenth and twentieth centuries after the excavation of a boxful of tabulae ceratae at Pompeii in 1875. It was Davenport $[47,48]$ and Taussig $[49]^{47}$ who invented the modern concept of funds in relation to the banking operations as is summarized and illustrated in Tsujimura $\mathrm{K}$ and Tsujimura M [17]. Funds are created when a bank credits customer's account with deposit and the customer incurs loan liability; funds are removed from circulation when the loan is paid off. Alternatively, funds are created when a bank purchases negotiable instruments such as Treasury Securities from its customer, and the funds are eliminated when the instruments are sold back or redeemed; ${ }^{48}$ central banks often create funds by purchasing bonds through open market operations. The funds circulate in the economy as a means

\footnotetext{
${ }^{46}$ Bank loans are also classified as mutuum in the aforementioned Justinian Institutiones because it was edited around $530 \mathrm{CE}$ in the Byzantine Empire that had officially adopted gold standard. In 330 CE, Constantine I officially moved the capital of the Roman Empire to Constantinople, which he founded as a second Rome on the site of Byzantium, an intercontinental city strategically located between Europe and Asia. Constantine monetary reform introduced a gold specie standard system by circulating solidus specie coins, which was minted from the gold confiscated from the pagan temples after his conversion to Christianity.

${ }^{47}$ Although they seldom refer each other in their writings, both Davenport and Taussig were studying at Harvard Law School just after the excavation of Pompeii.

${ }^{48}$ In the Roman law context, the sale and purchase of negotiable instruments are not categorized as emptio venditio (sale/purchase) but as subrogatio (subrogation), in which the 'buyer' or subrogationi (subrogee) repays the debt in place of the issuer of the instrument and takes over the position of the creditor from the 'sellor' or subrogationis (subrogor).
}

of payment, which is referred to as transfer of funds in a broad sense; 'payment' today is synonymous with 'transfer of funds'.

It is not widely known, though, the first economist who made a systematic use of 'flow of funds' account was Ragnar Frisch [50]. ${ }^{49}$ He not only invented the concept of open market operation, the indispensable tool for modern central banking, ${ }^{50}$ but also demonstrated the effects of the operations with his threesector five-instrument model. The three sectors, the central bank, commercial (and savings) banks and the non-bank sector, make and receive payments through five instruments: banknotes, reserve deposit, bank deposits, bank loans and the open market operations. The payments between the sectors are summarized in Table 2. While nonbank sector holds its funds as 'bank deposits', the commercial banks deposit their funds at the central bank as 'reserve deposit'. The commercial banks lend their funds to the nonbank sector. In this model, banknotes are assumed to be inconvertible. In such a case, a banknote is merely an order directing the issuing bank to shift a designated amount of funds to bearer's account. The funds are shifted from the customer's account to an inscribed deposit pool upon the issuance of a banknote; then the funds are shifted from the deposit pool to the bearer's account upon presentment. Thus, the funds are shifted from the nonbank sector to the central bank at the issuance, and are paid back to the nonfinancial sector when the notes are returned to the central bank. Nonfinancial transactions are excluded from the table because neither the central

\footnotetext{
${ }^{49}$ The paper was published as a core of the report prepared by the Monetary Committee of the Norwegian parliament in 1935 that recommended the Norges Bank, the central bank, should start using open market operations in a systematic manner in order to invigorate the credit creation process in the commercial and savings banks; see Eitrheim, Klovland and Øksendal (eds.) [51, p. 371].

${ }^{50}$ The US Federal Reserve adopted the open market operation for the first time in 1942 to assist the Treasury's war financing and has been using it ever since as its main policy instrument; see Humpage [52] for details.
} 
bank nor the commercial banks are assumed to engage in nonfinancial transactions.

In the above scenario, the central bank solely supplies the necessary funds through open market operations. Frisch manually calculated the propagation process of the payments through the payer-payee relationship between the sectors to show the effects of the open market operations. More recently the above-mentioned Tsujimura $\mathrm{K}$ and Tsujimura $\mathrm{M}$ [17] used the matrix algebra proposed by Stone [53] and Klein [54] to apply the Frisch's model to the U.S. quantitative easing, a countermeasure to the collapse of the subprime mortgage bubble of the noughties. Tsujimuras' study is not based on the present-day style Flow of Funds Accounts or Financial Accounts, ${ }^{51}$ instead, they made a pseudo 'flow of funds' matrix using the Integrated Macroeconomic Accounts for the United States, which covers both the financial and nonfinancial activities, as source data. The authors sincerely hope that this experiment is the first small step to fulfill the Mitchell and Copeland's dream - to understand the interactions between the financial and nonfinancial economy so as not to repeat the bitter experience of the 1930s.

\section{Acknowledgments}

The authors wish to thank the Editor-in-Chief Dr. Pieter Everaers and the anonymous referees for their constructive comments and useful suggestions.

\section{References}

[1] Hicks JR. The Social Framework: An Introduction to Economics. Oxford: Clarendon Press; 1942.

[2] Van Cleeff DE. Nationale boekhouding: proeve van een jaaroverzicht nederland 1939. De Economist. 1941; 90(1): 415-424.

[3] Derksen JBD. A System of National Book-keeping: Illustrated by the Experience of the Netherlands Economy. Cambridge: Cambridge University Press; 1946.

[4] Stone JRN. Definition and Measurement of the National Income and Related Totals. A memorandum prepared for the meeting of the Subcommittee on National Income Statistics of

\footnotetext{
${ }^{51}$ Tsujimura and Mizoshita [55] as well as Tsujimura and Tsujimura [56] used present-day style Flow of Funds Accounts as source data. The former was an attempt to simulate the effects of the world's first quantitative easing that the Bank of Japan implemented between 2001 and 2005; however, not a few central bankers criticized the analysis by suggesting it was misleading because the analysis used the present-day style Flow of Funds Accounts as source data ignoring the policy effects on the nonfinancial economy.
}

the League of Nations Committee of Statistical Experts held at Princeton, NJ; 1945. Reprinted in: United Nations. Measurement of National Income and the Construction of Social Accounts; 1947

[5] Aukrust O. On the theory of social accounting. Review of Economic Studies. 1949; 16(3): 170-188.

[6] Mitchell WC. The Flow of Payments: A Preliminary Survey of Concepts and Data. A memorandum, New York: National Bureau of Economic Research; 1944.

[7] Copeland MA. Tracing money flows through the united states economy. American Economic Review. 1947; 37(2): 31-49.

[8] Copeland MA. Social accounting for moneyflows. Accounting Review. 1949; 24(3): 254-264.

[9] Copeland MA. A Study of Moneyflow in the United States. New York: National Bureau of Economic Research; 1952.

[10] Shishido S. Kokumin Chochiku no Junkan. Tokyo: Chuo Keizai-sha; 1956.

[11] Kuznets SS. National Income and Capital Formation 1919 1935. New York: National Bureau of Economic Research; 1937.

[12] Meade JE, Stone JRN. The construction of tables of national income, expenditure, savings and investment. Economic Journal. 1941; 51(202): 216-233.

[13] Board of Governors of the Federal Reserve System. Flow of Funds in the United States 1939-1953. Washington: Board of Governors of the Federal Reserve System; 1955.

[14] De Bonis R, Gigliobianco A. The Origins of Financial Accounts in the United States and Italy: Copeland, Baffi and the Institutions. In: De Bonis R, Pozzolo AF, eds. The Financial Systems of Industrial Countries: Evidence from Financial Accounts. Heidelberg: Springer; 2012. pp. 15-49.

[15] Ricardo D. Proposals for an Economic and Secure Currency: With Observations on the Profits of the Bank of England. London: John Murray; 1816.

[16] Banks A. The U.K. Flow of Funds Project: Identifying Sectoral Interconnectedness in the U.K. economy. New Port: Office for National Statistics; 2016.

[17] Tsujimura K, Tsujimura M. A flow of funds analysis of the U.S. quantitative easing. Economic Systems Research. 2018; 30(2): 137-177.

[18] Taylor SP. From Moneyflows Accounts to Flow-of-Funds Accounts. A paper prepared for the annual meeting of the American Statistical Association, 1991. Reprinted in: Dawson JC, ed. Flow-of-Funds Analysis: A Handbook for Practitioners. Armonk: M. E. Sharp; 1996. pp. 101-108.

[19] Keynes JM. The General Theory of Employment, Interest and Money. London: Macmillan; 1936.

[20] Carver TN. The Distribution of Wealth. New York: Macmillan; 1904

[21] Cassel KG. The Nature and Necessity of Interest. London: Macmillan; 1903.

[22] Mitchell WC. Flow of Money Payments. In: Mitchell WC, ed. The National Bureau's First Quarter Century. New York: National Bureau of Economic Research; 1945. pp. 61-62.

[23] Allen FL. Only Yesterday: An Informal History of the 1920s. New York: Harper and Row; 1931.

[24] Allen FL. Since Yesterday: The 1930s in America. New York: Harper and Row; 1939.

[25] Banham R. The Ford Century: Ford Motor Company and the Innovations that Shaped the World. New York: Artisan; 2002.

[26] Sennett T. Hollywood Musicals. New York: H. N. Abrams; 1981.

[27] Leblebici H, Salancik GR, Copay A, King T. Institutional change and the transformation of interorganizational fields: an 
organizational history of the U.S. radio broadcasting industry. Administrative Science Quarterly. 1991; 36(3): 333-363.

[28] Galbraith JK. The Great Crash 1929. Boston: Houghton Mifflin; 1954.

[29] Wicksell K. Influence of the rate of interest on prices. Economic Journal. 1907; 17(66): 213-220.

[30] Mommsen T. Römische Geschichte. Berlin: Weidmann; 1885.

[31] Austin J. Lectures on Jurisprudence, or The Philosophy of Positive Law. London: John Murray; 1863.

[32] Smith W, ed. A Dictionary of Greek and Roman Antiquities. 3rd ed. London: John Murray; 1873.

[33] Berger A. Encyclopedic Dictionary of Roman Law. Philadelphia: American Philosophical Society; 1953.

[34] De Petra G. Le Tavolette Cerate di Pompei. Rome: Coi Tipi del Salviucci; 1876.

[35] Steinberg M. The twelve tables and their origins: an eighteen century debate. Journal of the History of Ideas. 1982; 43(3): 379-396.

[36] Hunter WA. A Systematic and Historical Exposition of Roman Law in the Order of a Code. London: Sweet and Maxwell; 1876.

[37] Belloni GG. La Moneta Romana: Società, Politica, Cultura. Rome: Carocci; 1993.

[38] De Zulueta F. Recent controversy about nexum. Law Quarterly Review. 1913; 29(2): 137-153.

[39] Schiller AA. Roman Law: Mechanisms of Development. Paris: Mouton; 1978.

[40] Harl KW. Coinage in the Roman Economy, 300 B.C. to A.D 700. Baltimore: The Johns Hopkins University Press; 1996.

[41] Dundas GS. Augustus and the kingship of egypt. Historia 2002; 51(4): 433-448.

[42] Morcillo MG. Auctions, Bankers and Public Finances in the Roman World. In: Koenrand V, Vandorpe K, Chankowski V, eds. Pistoi dia Tèn Technèn: Bankers, Loans and Archives in the Ancient World. Leuven: Peeters; 2008. pp. 257-275.
[43] Bove L. Documenti Processuali dale Tabulae Pompeianae di Murecine. Naples: Liguori; 1979.

[44] Mau A. Pompeji in Leben und Kunst. Leipzig: Wilhelm Engelmann; 1900.

[45] Petrucci A. Mensam Exercere: Studi sull'Impressa Finanziaria Romana. Naples: Jovene; 1991.

[46] Ruggles R. An Introduction to National Income and Income Analysis. New York: McGraw-Hill; 1949.

[47] Davenport HJ. Value and Distribution. Chicago: University of Chicago Press; 1908.

[48] Davenport HJ. The Economics of Enterprise. New York: Augustus M. Kelley; 1913.

[49] Taussig FW. Principles of Economics. New York: Macmillan; 1911.

[50] Frisch RAK. Open Market Operations og deres virkninger pa banksystemet. In: Innstilling om Markedsoperasjonen avgit av Komiteen til Utredning av Økonomiske og Pengepolitiske Sporsmal. Oslo: Sosialøkonomisk Samfunn; 1935. pp. 43-60.

[51] Eitrheim Ø, Klovland JT, Øksendal LF, eds. A Monetary History of Norway 1816-2016. Cambridge: Cambridge University Press; 2016

[52] Humpage OF. The Fed's Yield-Curve-Control Policy. Federal Reserve Bank of Cleveland Economic Commentary, 2016-15; 2016.

[53] Stone JRN. The social accounts from a consumer's point of view. Review of Income and Wealth. 1966; 12(1): 1-33.

[54] Klein LR. Lectures in Econometrics. Amsterdam: NorthHolland; 1983.

[55] Tsujimura K, Mizoshita (Tsujimura) M. Asset-liabilitymatrix analysis derived from flow-of-funds accounts: the bank of japan's quantitative monetary policy examined. Economic Systems Research. 2003; 15(1): 51-67.

[56] Tsujimura M, Tsujimura K. Balance sheet economics of the subprime mortgage crisis. Economic Systems Research. 2011; 23(1): 1-25. 